\title{
Photosynthetic Declines in Phytophthora ramorum-Infected Plants Develop Prior to Water Stress and in Response to Exogenous Application of Elicitins
}

\author{
Daniel K. Manter, Rick G. Kelsey, and Joseph J. Karchesy
}

First author: United States Department of Agriculture (USDA) Agricultural Research Service, Ft. Collins, CO, 80526; second author: USDA Forest Service, Pacific Northwest Research Station, Corvallis, OR 97331; and third author: Oregon State University, Wood Science and Engineering Department, Corvallis 97331. Accepted for publication 26 January 2007.

\begin{abstract}
Manter, D. K., Kelsey, R. G., and Karchesy, J. J. 2007. Photosynthetic declines in Phytophthora ramorum-infected plants develop prior to water stress and in response to exogenous application of elicitins. Phytopathology $97: 850-856$.

Phytophthora ramorum, causal agent of sudden oak death, is responsible for widespread oak mortality in California and Oregon, and has the potential to infect 100 or more species. Symptoms range from stem girdling and shoot blight to leaf spotting. In this study, we examined the physiological impacts of $P$. ramorum infection on Rhododendron macrophyllum. In stem-inoculated plants, photosynthetic capacity $\left(V_{\mathrm{cmax}}\right)$ significantly declined by $\approx 21 \% 3$ weeks after inoculation in visibly asymp-

closure and additional declines in photosynthetic capacity. We also report the isolation, characterization, and biological activity of two P. ramorum elicitins. Both elicitins were capable of inducing a hypersensitive-like response in one incompatible (Nicotiana tabacum SR1) and three compatible hosts ( $R$. macrophyllum, Lithocarpus densiflorus, and Umbellularia californica). Infiltration of leaves from all three compatible hosts with both $P$. ramorum elicitins caused significant declines in chlorophyll fluorescence $\left(F_{\mathrm{v}} / F_{\mathrm{m}}\right)$. For all four species, the loss of photosynthetic capacity was directly proportional to $\mathrm{H}^{+}$uptake and ethylene production, two common components of the hypersensitive response. This is the first report of elicitins causing photosynthetic declines in compatible hosts independent of plant water stress.
\end{abstract} tomatic leaves. By 4 weeks, after the development of significant stem lesions and loss in water transport capacity, water stress led to stomatal

Sudden oak death (SOD), caused by the oomycete Phytophthora ramorum, was first reported in trees of North America in 1995, and threatens to radically alter the composition of North American forests (39). SOD has caused significant mortality in natural stands of several tree species, including Quercus agrifolia (coast live oak), Q. kelloggii (California black oak), Q. parvula (coast oak), and Lithocarpus densiflorus (tanoak) from central California to southern Oregon (40). However, this disease is not limited to forest situations, because a variety of ornamental species have been found to be suitable hosts from 12 plant families, including Aceraceae, Anacardiaceae, Betulaceae, Caprifoliaceae, Cupressaceae, Ericaceae, Fagaceae, Hippocastanaceae, Lauraceae, Pinaceae, Rhamnaceae, and Rosaceae (17), and the list keeps growing.

Symptoms of $P$. ramorum infection fall into three separate categories: (i) bole cankers that often lead to death, (ii) shoot tip dieback, and (iii) leaf spots or blight (20). Depending upon the host species, $P$. ramorum infection may develop one or more of these symptoms. For example, L. densiflorus (tanoak) exhibits all three symptoms, Rhododendron macrophyllum (rhododendron) develops shoot tip dieback or leaf blight, and Umbellularia californica (myrtle) is typified by leaf blight. The distribution of P. ramorum within host tissues normally is associated only with visibly symptomatic tissues and may be confined to particular tissues (stem or leaves) (21). SOD derives its name from the rapid transition from

Corresponding author: D. K. Manter; E-mail address: daniel.manter@ars.usda.gov

doi:10.1094/PHYTO-97-7-0850

This article is in the public domain and not copyrightable. It may be freely reprinted with customary crediting of the source. The American Phytopathological Society, 2007.
Additional keywords: photosynthesis, toxin. green, nonsymptomatic crowns to brown, dead crowns in a period of weeks $(18,33)$. However, despite its name, mortality associated with SOD in natural stands may take several years to develop, is largely limited to the red oak and tanoak, and is typified by a consistent sequence of signs and symptoms beginning with the development of bleeding bole cankers, followed by bark or ambrosia beetle infestation, and Hypoxylon thouarsianum infection (32). In the absence of the latter two pests, McPherson et al. (32) estimate that it may take 10 years or more to reach a $50 \%$ mortality rate, or just 3 years in their presence.

Infection of compatible plants by Phytophthora spp. often leads to a decline in stomatal conductance and photosynthesis $(8,9,15$, $16,25,29,30,44)$, although the mechanistic basis for such declines is not completely understood. In many cases, declines in leaf gas exchange rates have been linked to losses in water supply capacity associated with root or xylem necrosis $(8,9,15,16,41,42)$. However, the reductions in gas exchange may not be proportional to changes in hydraulic capacity $(9,29)$, and may be observed in noninvaded regions (11), suggesting the presence of a toxin, or host-derived signal, that is responsible for some of the physiological impairment.

To date, a wide variety of secreted, translocatable effectorspathogen molecules that manipulate host cell structure and function affecting pathogenicity and colonization-have been identified in a variety of Phytophthora spp. (24). Effectors may either facilitate infection (virulence factors or toxins) or limit infection (avirulence factors or elicitins), and differences in the timing or degree of host responses may cause the same effector to be a virulence factor in one host or an avirulence factor in another host (10). In P. ramorum, numerous effector genes (e.g., NPP1, PcF, Crn, elicitins, and so on) homologous to those found in other Phytophthora spp. have been identified in its genome (45). 
In the current study, we first conducted a series of experiments to determine whether toxins secreted by $P$. ramorum are likely contributors to physiological injury in the host by examining the temporal changes in photosynthesis, stomatal conductance, and hydraulic conductivity of $R$. macrophyllum artificially inoculated with $P$. ramorum. Second, we tested the ability of culture filtrates and purified, recombinant $P$. ramorum elicitins (i.e., the major protein secreted in $P$. ramorum grown in vitro) to induce physiological changes in incompatible (Nicotiana tabacum) and compatible (L. densiflorius, R. macrophyllum, and U. californica) host species.

\section{MATERIALS AND METHODS}

Plant material. All artificial inoculations assays were conducted on 3-year-old $R$. macrophyllum plants grown in 7.6-liter pots. The biological activity of purified $P$. ramorum elictins was assessed on four plant species (N. tabacum SR1, L. densiflorus, $R$. macrophyllum, and $U$. californica). $N$. tabacum plants were $\approx 1$ month old and grown in a greenhouse under amibient conditions, L. densiflorus plants were 2 years old and grown under ambient conditions in a coldframe at Oregon State University (Corvallis), and $U$. californica leaf tissue was harvested from an ornamental planting on the campus of Oregon State University.

Physiological response of $R$. macrophyllum to artificial inoculation. To determine whether toxins secreted from $P$. ramorum contribute to physiological injury in the host, two stems $(\approx 2.5 \mathrm{~cm}$ in diameter) from each of 123 -year-old $R$. macrophyllum plants were artificially inoculated with a 5-mm-diameter hyphal plug cut from $\approx 2$ week old $P$. ramorum starter cultures ( $2 \%$ cornmeal agar) or uninoculated control plates, which was secured under the bark, $\approx 15 \mathrm{~cm}$ below the lowest leaf, using $\mathrm{dH}_{2} \mathrm{O}$-saturated gauze. The $P$. ramorum isolate used for inoculation was a North American mating type (A2) obtained from infected native plants growing in Curry County, OR. On a weekly basis (1 to 4 weeks after inoculation), $A / C_{\mathrm{i}}$ curves (net $\mathrm{CO}_{2}$ assimilation over a range of $\mathrm{CO}_{2}$ concentrations), stem-specific hydraulic conductivity, and stem lesion lengths were monitored.

$A / C_{\mathrm{i}}$ curves were measured on one leaf from each control and inoculated stem $(n=6)$ using an LI-6400 portable photosynthesis system (Li-Cor, Lincoln, NE) following the procedures outlined in Manter and Kerrigan (27). The $A / C_{\mathrm{i}}$ curves were used to estimate one of the biochemical components (the maximum rate of carboxylation limited by the amount, activity, and kinetics of rubisco $\left.\left[V_{\mathrm{cmax}}\right]\right)$ contributing to photosynthetic capacity using the equations of Farquhar et al. (13). In addition, stomatal conductance $\left(g_{\mathrm{s}}\right)$ of water vapor at ambient $\mathrm{CO}_{2}(40 \mathrm{~Pa})$ also is reported.

Stem-specific hydraulic conductivity $\left(K_{\mathrm{S}}\right)$, a measure of water transport capacity, was measured on a $3-\mathrm{cm}$ segment cut from a nonsymptomatic region immediately above the inoculation site of each control and inoculated stem $(n=3)$ using the procedures outlined in Manter and Kavanagh (26). The same seedlings $(n=$ 3 ) destructively sampled for $K_{\mathrm{S}}$ were used for measurements of lesion lengths (in centimeters) by recording discolored phloem tissue after removal of bark tissue.

Verification of $P$. ramorum infection within the tissues of the artificially inoculated $R$. macrophyllum plants was determined by direct plating on a Phytophthora spp.-selective medium (pimaricin-ampicillin-rifampicin-pentachloronitrobenzene agar, [PARP]) (12). On each sample date, $1-\mathrm{cm}^{2}$ pieces $(n>3)$ from symptomatic (lesion margin) and nonsymptomatic phloem tissues and the leaves used for gas exchange analysis were plated on PARP media, incubated in the dark at 20 to $22^{\circ} \mathrm{C}$, and examined daily over the course of 3 weeks for $P$. ramorum emergence.

Culture filtrate protein isolation. $P$. ramorum culture filtrates (CFs) were collected by vacuum filtration $(0.2 \mu \mathrm{m}$ PES membrane vacuum filter; VWR, West Chester, PA) from three North American (mating type A2) isolates obtained from infected native plants growing in Curry County, OR, and three European (mating type A1) isolates obtained from infected ornamental nursery plants in Clackamas, OR, grown in glucose-yeast-peptone (GYP) broth for 30 days. Proteins contained in the filtrate were concentrated and washed with 3 volumes of double-distilled (dd) $\mathrm{H}_{2} \mathrm{O}$ using a Vivacell 200 filtration column with a 5,000 MWCO PES membrane (Sartorius, Edgewood, NY). CF proteins were separated by ion exchange spin columns (Vivapure S mini; Sartorius) using a Tris$\mathrm{Cl}$ (pH 6.0) buffer system and analyzed on a $12 \%$ Tris-glycine gel by sodium dodecyl sulfate polyacrylamide gel electrophoresis (SDS-PAGE). All six $P$. ramorum isolates secreted two major proteins $(\approx 8$ and $10 \mathrm{kDa}$ ) that were purified by ion chromatography (Fig. 1). The two proteins were excised from the SDSPAGE gels, digested with trypsin, analyzed by matrix-assisted laser desorption/ionization time of flight mass spectrometry MALDI TOF/TOF, and tentatively identified by the Mascot homology search engine (Macromolecular Resources, Colorado State University, Fort Collins). In all six isolates, the $8-\mathrm{kDa}$ protein exhibited high homology to ubiquitin and the 10-kDa protein was similar to the elicitin of $P$. cinnamomi (Table 1). Similarly, the presence of ubiquitin and an elicitin in the CF of $P$. infestans also was observed by Huet et al. (22).

Cloning and expression of $P$. ramorum elicitins. A search of the $P$. ramorum genome project (DOE Joint Genome Project, United States Department of Energy, Walnut Creek, CA) revealed five sequences coding for recognizable elicitin proteins (protein

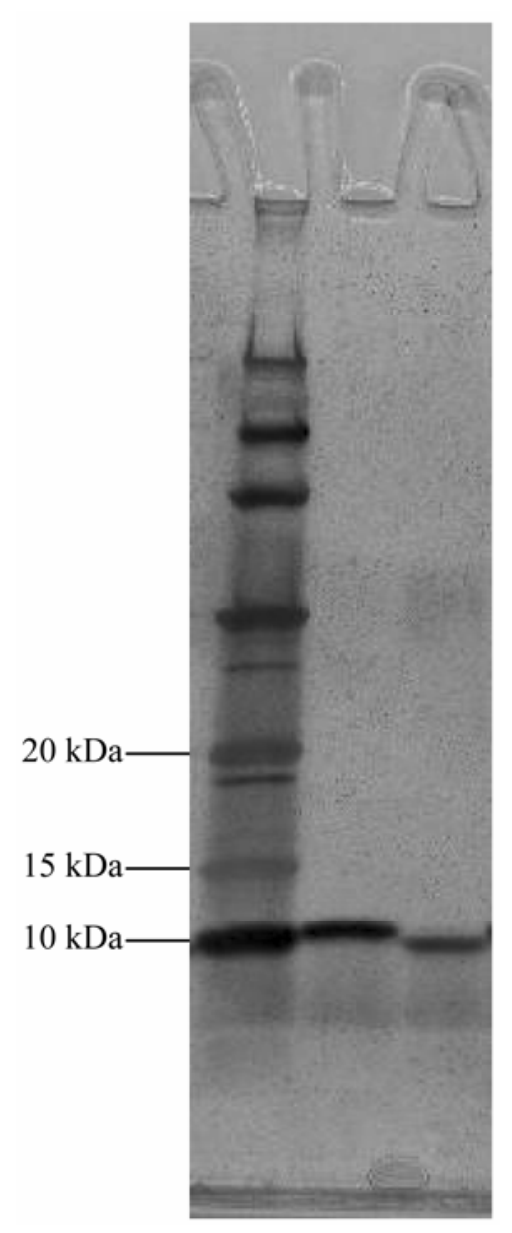

Fig. 1. Proteins present in the culture filtrate of a typical Phytophthora ramorum isolate grown in glucose-yeast-peptone media. The two major proteins of the culture filtrate were separated by ion affinity chromatography (Vivaspin S column) and analyzed on a $12 \%$ Tris-glycine gel by sodium dodecyl sulfate polyacrylamide gel electrophoresis. Lane 1: size standard, lane 2: fraction containing the $10-\mathrm{kDa}$ elicitin protein, and lane 3: fraction containing the 8-kDa ubiquitin protein. 
ID: 47381, 47386, 47376, 71636, and 78569). Based on these sequences, two conserved primer sets were designed to amplify fulllength elicitin genes. High homology between the gene sequences prevented the design of individual primer sets for all five sequences. Primer sets were as follows: ram- $\alpha 1$ (5'-ATGAACTTCCGCGCCCTG-3' and 5'-TTACAGCGACGCGCACGT-3') and ram- $\alpha 2$ (5'-ATGCAGTTCGCCGCTCTC-3' and 5'-CTACAGCGACGCACACGT- $3^{\prime}$ ). The two primer sets were tested on six different $P$. ramorum isolates, producing two unique elicitin proteins common to all six isolates (Fig. 2).

Recombinant ram- $\alpha 1$ and ram- $\alpha 2$ elicitins were obtained with the pET SUMO expression system (Invitrogen, Carlsbad, CA) as follows. Overnight bacterial cultures grown in Luria-Bertani broth, amended with kanamycin at $100 \mu \mathrm{g} \mathrm{ml}^{-1}$, were diluted 1:10 with fresh media, grown at $37^{\circ} \mathrm{C}$ until midlog phase (optical density $\approx 0.6$ ), induced with $1.0 \mathrm{mM}$ isopropyl- $\beta$-D-thiogalactopyranoside, and incubated for $6 \mathrm{~h}$ at $37^{\circ} \mathrm{C}$. Cells were harvested by centrifugation and soluble proteins were isolated using B-PER (Pierce Biotechnology, Rockford, IL). The recombinant proteins were purified by affinity chromatography (ProBond Resin; Invitrogen) using the following solvent system. After initial binding, the column was washed twice with $8 \mathrm{ml}(100 \mathrm{mM}$ Tris, $\mathrm{pH} 6.0$; $100 \mathrm{mM} \mathrm{NaCl}$; and $25 \mathrm{mM}$ imidazole) and eluted with $2 \mathrm{ml}(100$ $\mathrm{mM}$ Tris, $\mathrm{pH}$ 6.0; $100 \mathrm{mM} \mathrm{NaCl}$; and $250 \mathrm{mM}$ imidazole). Native elicitins, his-tag, and SUMO fusion protein removed with SUMO protease were purified by a second round of affinity chromatogra- phy using the conditions described above. The purified recombinant elicitins, contained in the unbound fraction, were desalted ( $2 \mathrm{~K}$ MWCO Centriprep column), washed with three volumes of $\mathrm{ddH}_{2} \mathrm{O}$, and resuspended in $2 \mathrm{mM} \mathrm{N}$-2-hydroxyethylpiperazine$N^{\prime}$-2-ethanesulfonic acid (HEPES). The purity of the recombinant elicitins was verified visually by SDS-PAGE, and protein content was determined using the Coomassie (Bradford) protein assay.

$\mathbf{H}^{+}$uptake. Twenty 6-mm-diameter leaf discs were suspended in $10 \mathrm{ml}$ of a 2-mM HEPES bathing solution and the $\mathrm{pH}$ was recorded after a 30 -min equilibration period. Purified elcitins were added to half of the vials $(n=6)$ to a final concentration of $100 \mathrm{nM}$; the other half received an equal volume of a control solution. Following an additional 2-h incubation period, $\mathrm{pH}$ of the bathing solution was remeasured and used to calculate $\mathrm{H}^{+}$uptake $\left(\mu \mathrm{mol} \mathrm{m}{ }^{-2} \mathrm{LA} \mathrm{h}^{-1}\right)$.

Ethylene production. Ethylene production of leaf discs exposed to the purified elicitins was measured as follows. Briefly, 10 6-mm-diameter leaf discs were placed in 15-ml screw-cap vials containing $1 \mathrm{ml}$ of a $100-\mathrm{nM}$ elicitin solution or a control and incubated at $25^{\circ} \mathrm{C}$ for $16 \mathrm{~h}$. After incubation, ethylene present in the vial headspace was analyzed using a Varian CP-3800 gas chromatograph outfitted with a 2-m Hayesep N 80-100 mesh column. Oven conditions were $70^{\circ} \mathrm{C}$ with a flow rate of $10 \mathrm{ml} \mathrm{min}{ }^{-1}$ and ethylene was analyzed by means of an external standard curve.

TABLE 1. Typical Mascot mass spectrometry/mass spectrometry search results showing known proteins with high homology to the two proteins isolated from Phytophthora ramorum culture filtrates

\begin{tabular}{lccccc}
\hline Sample & Best match & Mass $(\mathrm{kDa})$ & Ion score & Expected ion score & Peptides matched \\
\hline Protein 1 & gi 136672 -ubiquitin & 8,575 & 105 & 2.9 e-007 & K.EGIPPDQQR.L \\
& $\ldots$ & $\ldots$ & $\ldots$ & $\ldots$ & K.ESTLHLVLR.L \\
& $\ldots$ & $\ldots$ & $\ldots$ & $\ldots$ & R.TLSDYNIQK.E \\
Protein 2 & $\ldots$ & 10,287 & $\ldots$ & $\ldots$ & K.TITLDVEPSDSIDNVK.Q \\
& $\ldots$ & $\ldots$ & $\ldots$ & 9.7 e-006 & -.TACTATQQTAAYK.T \\
& $\ldots$ & $\ldots$ & $\ldots$ & K.TLVSILSESSFSQCSK.K \\
& $\ldots$ & $\ldots$ & $\ldots$ & K.LMCASTACNTMIK.D \\
\hline
\end{tabular}

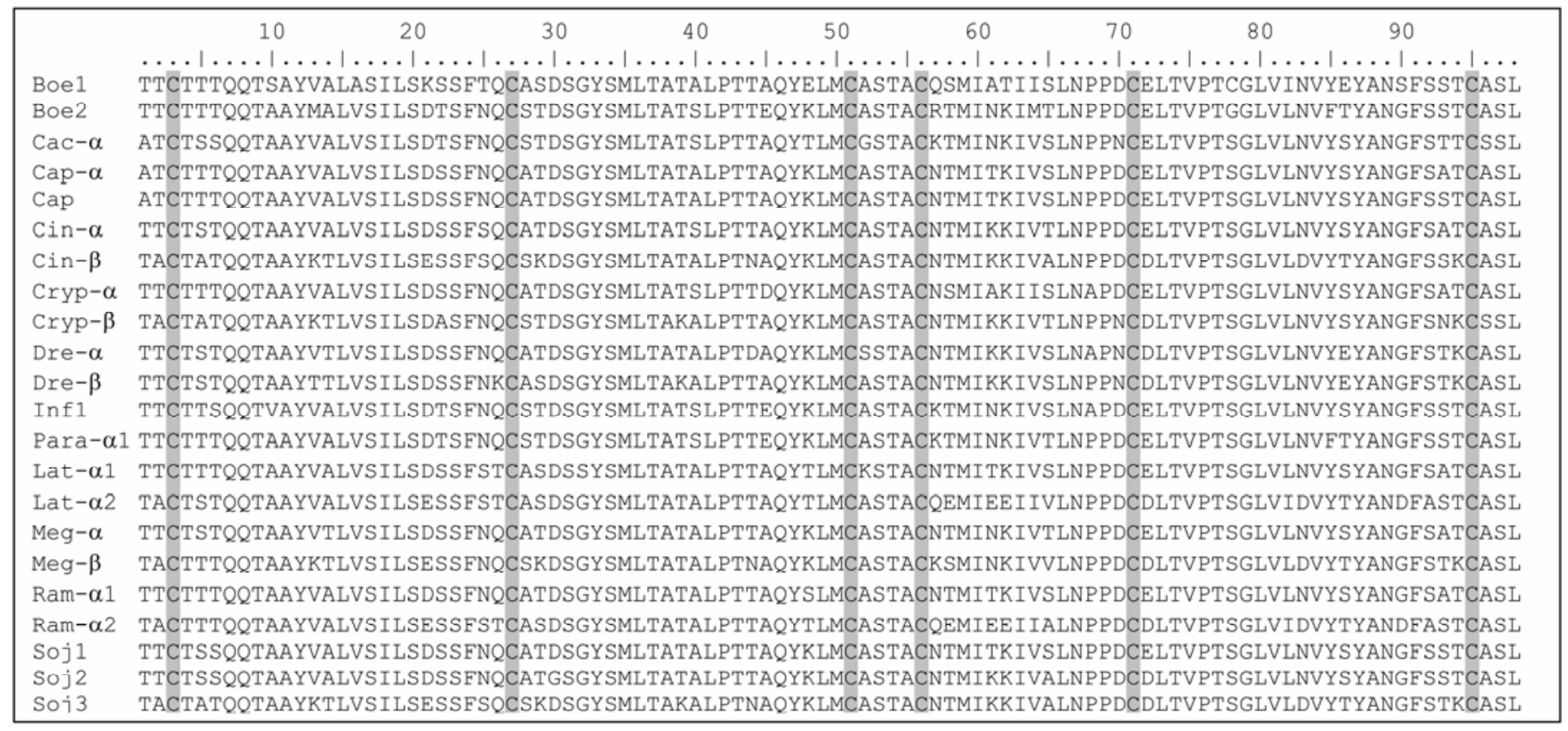

Fig. 2. Amino acid sequence of two Phytophthora ramorum elicitins and alignment with 20 class I elicitin sequences. P. boehmeriae: boe1 (AAP42950), boe2 (AAP42951); P. cactorum: cac- $\alpha$ (2009394A); P. capsici: cap- $\alpha$ (AAO15602), cap (AAP43023); P. cinnamomi: cin- $\alpha$ (CAB38323), cin- $\beta$ (CAB38321); P. cryptogea: cryp- $\alpha$ (P41802), cryp- $\beta$ (P15570), P. drechsleri: dre- $\alpha$ (P35696), dre- $\beta$ (P35697); P. infestans: inf1 (U50844); P. parasitica: para- $\alpha 1$ (AAB29433); P. lateralis: lat- $\alpha 1$ (DQ680028), lat- $\alpha 2$ (DQ680029); P. megasperma: meg- $\alpha$ (AJ493606), meg- $\beta$ (AJ493607); P. ramorum: ram- $\alpha 1$ (DQ680026), ram- $\alpha 2$ (DQ680027); P. sojae: soj1 (CAA07710), soj2 (CAA07711), soj3 (AA024640). GenBank accession number for each protein is in parentheses. Conserved cysteine residues are highlighted. 
Chlorophyll fluorescence. The effect of elicitins on photosynthetic performance was assessed by measuring chlorophyll fluorescence $\left(F_{\mathrm{v}} / F_{\mathrm{m}}\right)$ on dark-adapted leaves to determine the efficiency of open PSII centers, which is a sensitive measure of photosynthetic performance (31). Cut stems from all four test species were place in test tubes containing $10 \mathrm{ml}$ of a $100-\mathrm{nM}$ elicitin solution or a control and incubated in a growth chamber set to maintain air temperatures of 25 and $18^{\circ} \mathrm{C}$ (day and night, respectively) and a 16-h photoperiod. After a 48-h incubation period, chlorophyll fluorescence was measured using an OS1-FL fluorometer (Optisciences, Tyngsboro, MA) from one leaf per stem following a 30-min dark adaptation.

Statistical analyses. Significant differences between species and $P$. ramorum elicitins were tested by analysis of variance and Holm-Sidak post-hoc tests (SigmaStat 3.1). The Holm-Sidak post-hoc test applies a "step-down" critical $P$ value approach in determining significance to maximize statistical power without compromising the risk of making a type-I error (19). For comparison, the control in the CF-elicitin assays was uninoculated GYP

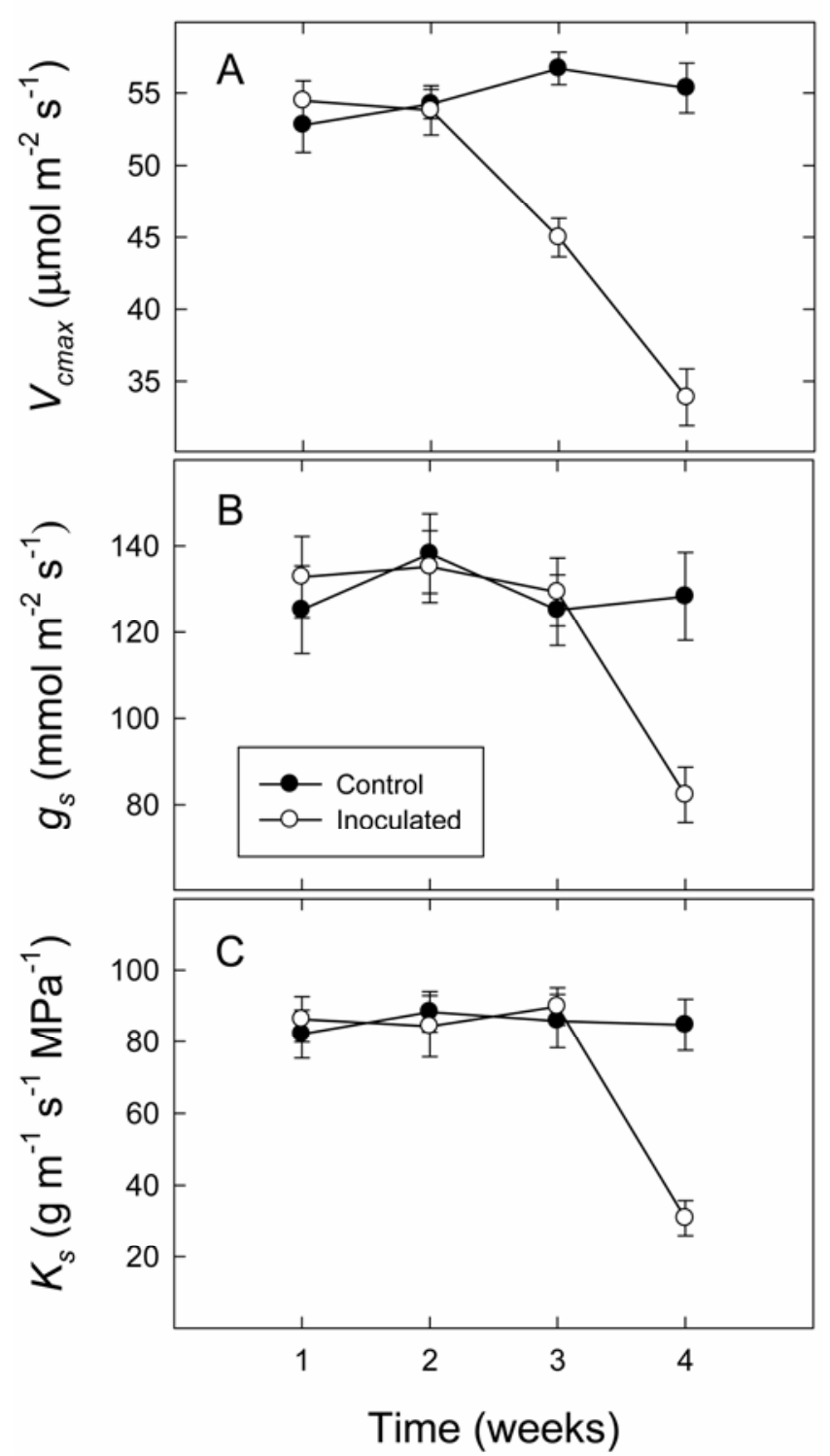

Fig. 3. A, Maximum rate of carboxylation limited by the amount, activity, and kinetics of rubisco $\left(V_{\mathrm{cmax}}\right), \mathbf{B}$, stomatal conductance $\left(g_{\mathrm{s}}\right)$, and $\mathbf{C}$, stem-specific hydraulic conductivity $\left(K_{\mathrm{S}}\right)$ of Rhododendron macrophyllum artificially inoculated with Phytophthora ramorum. Each observation is the mean and standard deviation of six plants, from which one control and one inoculated leaf were measured. media subjected to the same purification procedures outlined above (see "Culture filtrate protein isolation"). In the assays involving the recombinant elicitins (ram- $\alpha 1$ and ram- $\alpha 2$ ), the control was a $100 \mathrm{nM}$ solution of the SUMO-CAT fusion protein (Invitrogen) generated using the same purification procedures outlined above. All experiment-assay combinations were replicated twice with similar results. All reported values are the arithmetic mean and individual standard errors from the first replication of each experiment.

\section{RESULTS}

All artificial inoculations of $R$. macrophyllum were successful, resulting in an average lesion length of $6.9 \pm 0.9 \mathrm{~cm}$ by the end of the 4-week study. Reisolation of $P$. ramorum was $100 \%$ successful from all symptomatic stem tissues, but not from any of the asymptomatic stem or leaf tissues (data not shown). Physiological changes developed rapidly in leaves of the inoculated stems, despite the lack of visible symptoms in the leaves or petiole. Three weeks after inoculation, when stem lesion lengths were $4.4 \pm$ $0.6 \mathrm{~cm}, V_{\text {cmax }}$ was reduced by $\approx 21 \%$ (Fig. 3A). Additional declines occured during the fourth week, after the development of significant impacts on plant-water relations.

The functionality of $P$. ramorum infected stems to supply water to host leaves and maintain photosynthetic rates was assessed from $K_{\mathrm{S}}$ and $g_{\mathrm{s}}$ measurements. Four weeks after inoculation, but not before, both measures declined; $g_{\mathrm{s}}$, a measure of stomatal openness, declined by $36 \%$ (Fig. 3B), and $K_{\mathrm{S}}$, a measure of xylem water supply capacity, declined by $64 \%$ (Fig. 3C). A CF-derived elicitin from $P$. ramorum was purified and tested for its ability to influence leaf processes. Similar to the artificial inoculation experiment, the CF-elicitin caused a significant decline of $23.4 \%$ in photosynthetic capacity $\left(V_{\mathrm{cmax}}\right)$ and $14.8 \%$ in the efficiency of open PSII centers $\left(F_{\mathrm{v}} / F_{\mathrm{m}}\right)$ (Table 2$)$. Two components often associated with the hypersensitive response (HR), $\mathrm{H}^{+}$uptake and ethylene production, also were influenced by elicitin uptake, changing by 78.8 and $92.4 \%$, respectively (Table 2 ).

The genome database of $P$. ramorum contains five gene models that encode for mature 10-kDa elicitin protein (protein ID: 47376, 47381, 47386, 40636, and 78569). However, it is unknown which one or more of these elicitins are secreted into the CF. Therefore, we used a polymerase chain reaction (PCR)-based approach to isolate and clone full-length $P$. ramorum elicitin genes, which then could be tested for biological activity. Each primer set amplified one unique product (GenBank accession no. DQ680026 and DQ680027) that was identical for all six isolates tested (data not shown). The predicted amino acid sequences are shown in Figure 2. Although there are five different elicitin gene models in the $P$. ramorum genome database, based on our results and the high homology between sequences, it is likely that only two class-I

TABLE 2. Influence of a Phytophthora ramorum culture filtrate elicitin (CFelicitin) on various leaf physiological parameters in Rhododendron macrophyllum

\begin{tabular}{lccc}
\hline & \multicolumn{2}{c}{ Treatment $^{\mathrm{b}}$} & \\
\cline { 2 - 3 } Parameter $^{\mathrm{a}}$ & Control & CF-elicitin & Change $(\%)^{\mathrm{c}}$ \\
\hline$V_{\mathrm{cmax}}$ & $48.1 \pm 1.8$ & $36.8 \pm 1.7$ & $-23.4^{*}$ \\
$F_{\mathrm{v}} / F_{\mathrm{m}}$ & $0.813 \pm 0.003$ & $0.693 \pm 0.005$ & $-14.8^{*}$ \\
$\mathrm{H}^{+}$uptake & $2.8 \pm 1.3$ & $13.2 \pm 2.5$ & $78.8^{*}$ \\
Ethylene & $11.2 \pm 1.7$ & $148.2 \pm 5.9$ & $92.4^{*}$ \\
\hline
\end{tabular}

${ }^{a}$ Maximum rate of carboxylation limited by the amount, activity, and kinetics

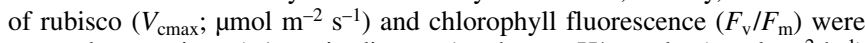
assayed on cuttings $\left(\approx 1 \mathrm{~cm}\right.$ in diameter), whereas $\mathrm{H}^{+}$uptake $\left(\mu \mathrm{mol} \mathrm{m} \mathrm{m}^{-2} \mathrm{~h}^{-1}\right)$ and ethylene production (ppb) were assayed on leaf discs immersed in a CFelicitin solution $(100 \mathrm{nM})$ or a control (uninoculated glucose-yeast-peptone media).

${ }^{\mathrm{b}}$ Mean \pm standard error for six plants per treatment.

c Asterisk denotes significant difference (Holm-Sidak post-hoc test, $P<0.05$ ). 


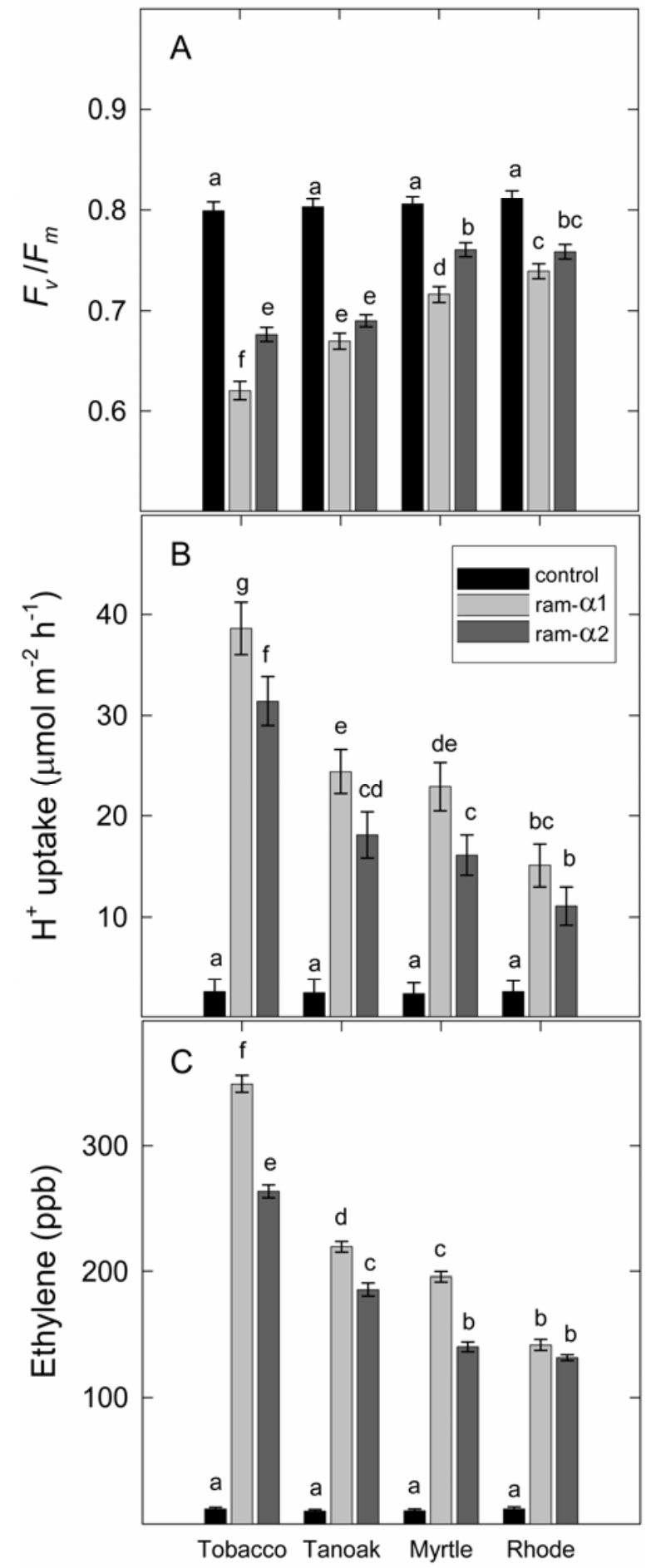

Fig. 4. A, Dark-adapted chlorophyll fluorescence $\left(F_{\mathrm{v}} / F_{\mathrm{m}}\right), \mathbf{B}, \mathrm{H}^{+}$uptake, and C, ethylene production in leaves of four plant species exposed to $100 \mathrm{nM}$ Phytophthora ramorum recombinant elicitins (ram- $\alpha 1$ and ram- $\alpha 2)$ or a control (100 nM SUMO-CAT fusion protein). Each observation is the mean and standard error $(n=6)$. Tobacco $=$ Nicotiana tabacum; Tanoak = Lithocarpus densiflorus; Myrtle = Umbellularia californica; Rhode $=$ Rhododendron macrophyllum. Bars with the same letter are not significantly different using a Holm-Sidak post-hoc test $(P>0.05)$.

elicitin genes are present in the $P$. ramorum genome. For the three ram- $\alpha 1$ homologs $(47381,47386$, and 78569), proteins 47381 and 78569 are identical to ram- $\alpha 1$; whereas, the gene sequence of protein 47386 differs from ram- $\alpha 1$ by only one nucleotide, resulting in an amino acid substitution at position 93 (threonine [T]). For the two ram- $\alpha 2$ homologs (47376 and 71636), protein 71636 is identical to ram- $\alpha 2$; whereas, the gene sequence of pro- tein 47376 differs from ram- $\alpha 2$ by only two nucleotides, resulting in amino acid substitutions at positions 61 (lysine [K]) and 65 (threonine [T]).

The two cloned elicitin genes were expressed using a prokaryotic expression system, and the purified recombinant elicitins were tested for biological activity in both compatible and incompatible hosts. Both recombinant elicitins produced a visible HR and developed necrotic areas when infiltrated into leaves of the incompatible host, N. tabacum; however, no macroscopically visible necrosis was observed in any of the three compatible hosts (data not shown). Independent of the development of visible necrosis, the recombinant elicitins significantly affected a variety of physiological characteristics of all four host species. In all species, exposure to recombinant elicitins caused a decline in the maximum efficiency of PSII centers or $F_{\mathrm{v}} / F_{\mathrm{m}}$ (Fig. 4A), while enhancing $\mathrm{H}^{+}$uptake (Fig. 4B) and ethylene production (Fig. 4C) relative to the controls. Thus, for all treatment combinations (elicitin and host species), the decline in $F_{\mathrm{v}} / F_{\mathrm{m}}$ was strongly and positively correlated to $\mathrm{H}^{+}$uptake (Fig. 5A) and ethylene production (Fig. 5B). As in the $\mathrm{CF}$ tests, tobacco exhibited the greatest responses, followed by tanoak, myrtle, and rhododendron. For all three measures (Fig. 4), ram- $\alpha 1$ triggered significantly greater responses compared with ram- $\alpha 2$, except in rhododendron, and in tanoak $F_{\mathrm{v}} / F_{\mathrm{m}}$.

\section{DISCUSSION}

Artificial inoculation of $R$. macrophyllum with $P$. ramorum led to significant declines in photosynthesis, $g_{\mathrm{s}}$, and water supply capacity. The temporal changes in these measures suggest that physiological impacts occur in two distinct phases. The first stage occurs prior to detectable changes in water supply capacity, and the second, additional decline occurs only after a reduction in stem-specific hydraulic capacity. The second phase of impact has been shown repeatedly for a variety of Phytophthora spp. pathosystems and is best explained by the loss of water supply capacity associated with root or shoot necrosis $(8,9,15,16,41,42)$. The first stage, independent of significant changes in water supply capacity, is consistent with previous studies $(9,29,30)$ and is suggestive of the presence of a toxin or a host-derived signal.

Although toxins have been suggested to play a role in Phytophthora spp. pathosystems, previous efforts to document elicitin toxicity in compatible hosts have met with varying degrees of success. For example, elicitin exposure did not influence $g_{\mathrm{s}}$ in chestnut (30) or net photosynthesis in beech (15). However, ultrastructural changes in oak (5) and pepper (23) and varying degrees of necrosis or cell apoptosis have been observed in several Solanaceae plants $(35,46)$ and the rubber tree $(6)$. Based on these observations and those of the current study, a wide range of host responsiveness to elictins is possible. Although the mechanistic basis for the observed photosynthetic declines was not fully explored in this study, we hypothesize that it is associated with an incomplete or hypersensitive-like response. In part, this hypothesis is based on the strong correlation between the decline in $F_{\mathrm{v}} / F_{\mathrm{m}}$ and two processes typically associated with HR: $\mathrm{H}^{+}$uptake $\left(R^{2}=\right.$ $0.801)$ and ethylene production $\left(R^{2}=0.884\right)$. To date, the vast majority of work with elicitins has focused on their ability to induce the HR and systemic acquired resistance in incompatible hosts such as tobacco $(2,38)$. Furthermore, both artificial inoculation (43) and elicitin exposure (28) result in photosynthetic declines in incompatible hosts. Part of this decline surely arises from the death of functional mesophyll cells during a successful HR. However, Scharte et al. (43) recently showed that a successful $\mathrm{HR}$ requires the suppression of photosynthesis, associated with callose depositon or sugar accumulation, before HR cell death can be initiated. Thus, it follows that host differences in the degree of the HR response to elicitins (i.e., highest in resistant species) could be the source of the observed photosynthetic de- 


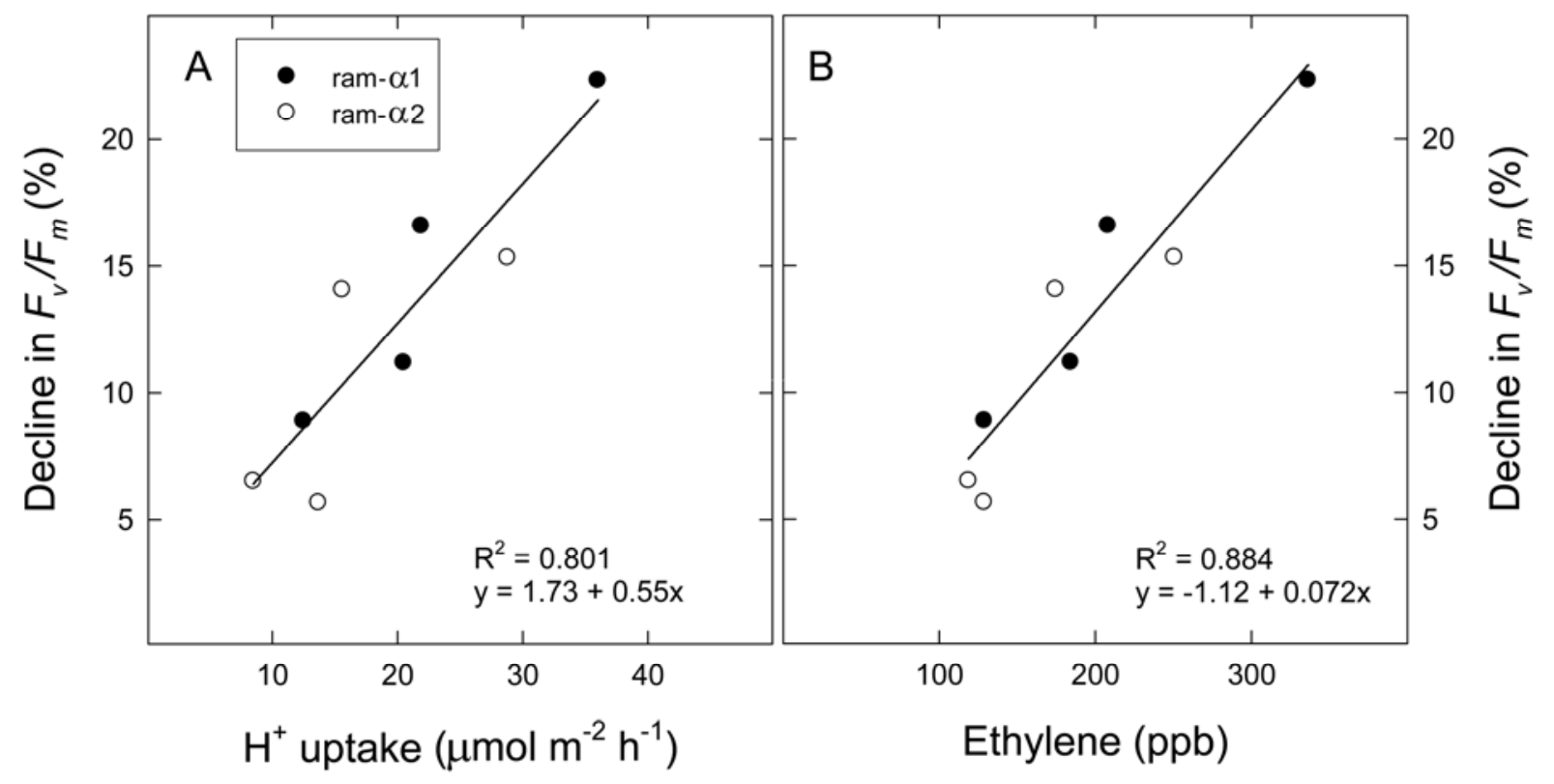

Fig. 5. Linear relationship between the relative changes in chlorophyll fluorescence of dark-adapted leaves chlorophyll fluorescence $\left(F_{\mathrm{v}} / F_{\mathrm{m}}\right)$ and $\mathbf{A}, \mathrm{H}^{+}$uptake or B, ethylene production. $F_{\mathrm{v}} / F_{\mathrm{m}}$ is percent change in recombinant elicitin-treated tissues (100 nM ram- $\alpha 1$ or ram- $\left.\alpha 2\right)$ relative to a control (100 nM SUMO-CAT fusion protein) and $\mathrm{H}^{+}$and ethylene are the absolute difference between the treated and control. Points represent the eight recombinant elicitin and host species combinations.

clines (i.e., highest in resistant species) in response to elicitin infiltration. Consistent with this hypothesis, Vleeshowers et al. (46) examined HR cell death in several Solanum clones and found a high degree of variation in the timing and degree of HR cell death, which was correlated with resistance to P. infestans. Finally, the notion of an effector triggering HR-like processes in both compatible and incompatible hosts is supported by other studies. For example, the NPP1 effector from Phytophthora spp. induces typical HR-associated (ethylene accumulation, callose deposition, and necrosis) and systemic-acquired resistance-associated (pathogenesis-related gene accumulation) processes in both compatible and incompatible host species $(14,37)$.

In all species, except rhododendron, ram- $\alpha 1$ consistently showed greater biological acitivty compared with ram- $\alpha 2$. Comparisons of the biological activity of a number of other Phytophthora elicitins suggests a general relationship between protein charge (pI) and activity. In particular, greater acitivity has been observed for the basic elicitins $(\mathrm{pI}>5)$ compared with the acidic elicitins ( $\mathrm{pI}<4)(35)$. Bourque et al. (3) suggest that this relationship may be explained by subtle differences in elicitin diffusion at physiological $\mathrm{pH}$ in the negatively charged cell wall.

Although neither of the two $P$. ramroum elicitins used in this study are basic elicitins ( $\mathrm{pI}>5$ ), greater activity was observed for the relatively more basic of the two $P$. ramorum elicitins ( $\mathrm{pI}$ of 3.84 and 3.13 for ram- $\alpha 1$ and ram- $\alpha 2$, respectively). Alternatively, Qutob et al. (36) compared the activity of nine elicitins from $P$. sojae and suggested that differences in elicitin activity may be related to their sterol-loading capacity. For example, elicitins with fewer amino acids interspacing the conserved cysteine residues (Fig. 2), which would result in a reduced sterol-binding tunnel (1), did not induce an HR response in tobacco. Although all known class I elicitins, including $P$. ramorum, have similar spacing between cysteine residues, subtle differences in sterolloading capacity, perhaps related to pI, could affect their biological activity $(3,4,34,47)$.

Although the current study shows the effect on exogenously applied elicitins, further studies are needed to explore the temporal and spatial patterns of $P$. ramorum elicitin expression during the infection cycle. For example, Colas et al. (7) showed that $P$. parasitica elicitin expression may be downregulated early on during the course of infection (3 days after infection), possibly to avoid a successful HR that is capable of limiting colonization. However, they did not follow elicitin expression throughout the full infection process and examined only one of the potential elicitin genes found in $P$. parasitica, parA1. In another study, Brummer et al. (5) used an enzyme-linked immunosorbent assay to show that $P$. quercina produced an elicitin, quercinin, in infected oak tissues during its entire growth phase. The pathogenor host-derived factors regulating elicitin production by Phytophthora spp. are unknown and deserve further research. It is possible that changes in elicitin expression or perception by the host are one of the greatest contributors to host variation in Phytophthora spp. resistance and pathogenicity. In our laboratory, we currently are using a reverse-transcriptase PCR assay to follow ram- $\alpha 1$ and ram- $\alpha 2$ expression throughout the infection process in a variety of host species.

In conclusion, we have shown that exogenous application of elicitins results in photosynthetic declines in both compatible and incompatible hosts. The mechanism responsible for the declines is unknown but arguably may be associated with quantitative differences in the timing and degree of the HR. In the compatible hosts studied here, a general correlation between $P$. ramorum colonization (21) and host responsiveness to $P$. ramorum elicitins is observed. Given the wide distribution of $P$. ramorum (more than 100 host species) and variety of disease forms, differences in elicitin expression, and perception by the host, may be one factor leading to this variation. However, because many other known effectors are contained in the $P$. ramorum genome, it is likely that host resistance and $P$. ramorum pathogenicity will be dependent upon the entire expression profile of $P$. ramorum effectors and host variations in responsivity to these effectors.

\section{ACKNOWLEDGMENTS}

Financial support from the United States Department of Agriculture Forest Service, including the Pacific Southwest Forest and Range Experiment Station and Regions 5 and 6, made this work possible.

\section{LITERATURE CITED}

1. Boissy, G., de La Fortelle, E., Kahn, R., Huet, J.-C., Bricogne, G., Pernollet, J.-C., and Brunie, S. 1999. Crystal structure of a fungal elicitor 
secreted by Phytophthora cryptogea, a member of a novel class of plant necrotic proteins. Structure 4:1429-1439.

2. Bonnet, P., Bourdon, E., Ponchet, M., Blein, J.-P., and Ricci, P. 1996. Acquired resistance triggered by elicitins in tobacco and other plants. Eur. J. Plant Pathol. 102:181-192.

3. Bourque, S., Binet, M.-N., Ponchet, M., Pugin, A., and Lebrun-Garcia, A. 1999. Characterization of the cryptogein binding sites on plant plasma membranes. J Biol. Chem. 274:34699-34705.

4. Bourque, S., Ponchet, M., Binet, M.-N., Ricci, P., Pugin, A., and LebrunGarcia, A. 1998. Comparison of binding properties and early biological effects of elicitins in tobacco cells. Plant Physiol. 118:1317-1326.

5. Brummer, M., Arend, M., Fromm, J., Schlenzig, A., and Oßwald, W. F. 2002. Ultrastructural changes in immunocytochemical localization of the elicitin quercinin in Quercus robur L. roots infected with Phytophthora quercina. Physiol. Mol. Plant Pathol. 61:109-120.

6. Churngchow, N., and Rattarasarn, M. 2000. The elicitin secreted by Phytophthora palmivora, a rubber tree pathogen. Phytochemistry 54:33-38.

7. Colas, V., Conrod, S., Venard, P., Keller, H., Ricci, P., and Panabières. F. 2001. Elicitin genes expressed in vitro by certain tobacco isolates of Phytophthora parasitica are down regulated during compatible interactions. Mol. Plant-Microbe Interact. 14:326-335.

8. Crombie, S. D., and Tippett, J. T. 1990. A comparison of water relations, visual symptoms, and changes in stem girth for evaluating impact of Phytophthora cinnamomi dieback on Eucalyptus marginata. Can. J. For. Res. 20:233-240.

9. Dawson, P., and Weste, G. 1982. Changes in water relations associated with infection by Phytophthora cinnamomi. Aust. J. Bot. 30:393-400.

10. Desender, S., Andrivon, D., and Val, F. 2006. Activation of defense reactions in Solanaceae: where is the specificity? Cell Microbiol. Online publication no. doi:10.1111/j.1462-5822.2006.00831.x

11. Duniway, J. M. 1977. Changes in resistance to water transport in safflower during the development of Phytophthora root rot. Phytopathology 67:331-337.

12. Erwin, D. C., and Ribeiro, O. K. 1996. Phytophthora Diseases Worldwide. The American Phytopathological Society Press, St. Paul, MN.

13. Farquhar, G. D., von Caemmerer, S., and Berry, J. A. 1980. A biochemical model of photosynthetic $\mathrm{CO}_{2}$ assimilation in leaves of $\mathrm{C} 3$ species. Planta 149:78-90.

14. Fellbrich, G., Romanski, A., Varet, A., Blume, B., Brunner, F., Engelhardt, S., Felix, G., Kemmerling, B., Krzymowska, M., and Nürnburger, T. 2002. NPP1, a Phytophthora-associated trigger of plant defense in parsley and Arabidopsis. Plant J. 32:375-390.

15. Fleischmann, F., Koehl, J., Portz, R., Bletrame, A. B., and Oßwald, W. 2005. Physiological changes of Fagus sylvatica seedlings infected with Phytophthora citricola and the contribution of its elicitin "citricolin" to pathogenesis. Plant Biol. 7:650-658.

16. Fleischmann, F., Schneider, D., Matyssek, R., and Oßwald, W. F. 2002. Investigations on net $\mathrm{CO}_{2}$ assimilation, transpiration and root growth of Fagus sylvatica infested with four different Phytophthora species. Plant Biol. 4:144-152.

17. Garbelotto, M., Davidson, J. M., Ivors, K., Maloney, P. E., Huberli, D., Koike, S. T., and Rizzo, D. M. 2003. Non-oak native plants are main hosts for sudden oak death pathogen in California. Calif. Agric. 57:18-23.

18. Garbelotto, M., Svihra, P., and Rizzo, D. M. 2001. Sudden oak death syndrome fells three oak species. Calif. Agric. 55:9-19.

19. Glantz, S. A. 2002. Primer of Biostatistics, 5th ed. McGraw-Hill, New York.

20. Goheen, E. M., Hansen, E., Kanaskie, A., Osterbauer, N., Parke, J., Pscheidt, J., and Chastagner, G. 2006. Sudden oak death and Phytophthora ramorum: A guide for forest managers, Christmas tree growers, and forest-tree nursery operators in Oregon and Washington. Oreg. State Univ. Ext. Serv. EM8877.

21. Hansen, E. M., Parke, J. L., and Sutton, W. 2005. Susceptibility of Oregon forest trees and shrubs to Phytophthora ramorum: a comparison of artificial inoculation and natural infection. Plant Dis. 89:63-70.

22. Huet, J. C., Sallé-Tourne, M., and Pernollet, J.-C. 1994. Amino acid sequence and toxicity of the alpha elicitin secreted with ubiquitin by Phytophthora infestans. Mol. Plant-Microbe Interact. 7:302-304.

23. Ivanova, D.G., and Singh, B. R. 2003. Nondestructive FTIR monitoring of leaf senescence and elicitin-induced changes in plant leaves. Biopolymers 72:79-85

24. Kamoun, S. 2006. A catalogue of the effector secretome of plant pathogenic oomycetes. Annu. Rev. Phytopathol. 44:41-60.

25. Koch, C., Noga, G., and Strittmatter, G. 1994. Photosynthetic electron transport is differentially affected during early stages of cultivar/racespecific interactions between potato and Phytophthora infestans. Planta 193:551-557.

26. Manter, D. K., and Kavanagh, K. L. 2003. Stomatal regulation in Douglas-fir following a fungal-mediated chronic reduction in leaf area. Trees 17:485-491.
27. Manter, D. K., and Kerrigan, J. 2004. $A / C_{\mathrm{i}}$ curve analysis across a range of woody plant species: influence of some regression analysis parameters and mesophyll conductance. J. Exp. Bot. 55:2581-2588.

28. Matsumura, H., Reich, S., Ito, A., Saitoh, H., Kamoun, S., Winter, P., Kahl, G., Reuter, M., Krüger, D. H., and Terauchi, R. 2003. Gene expression analysis of plant host-pathogen interactions by SuperSAGE. Proc. Natl. Acad. Sci. USA 100:15718-15723.

29. Maurel, M., Robin, C., Capdevielle, X., Loustau, D., and DesprezLoustau, M. L. 2001. Effects of variable root damage caused by Phytophthora cinnamomi on water relations of chestnut saplings. Ann. Sci. 58:639-652.

30. Maurel, M., Robin, C., Simonneau, T., Loustau, D., Dreyer, E., and Desprez-Loustau, M. L. 2004. Stomatal conductance and root-to-shoot signaling in chestnut saplings exposed to Phytophthora cinnamomi or partial soil drying. Funct. Plant Biol. 31:41-51.

31. Maxwell, K., and Johnson, G. N. 2000. Chlorophyll fluorescence-A practical guide. J. Exp. Bot. 51:659-668.

32. McPherson, B. A, Mori, S. R., Wood, D. L., Storer, A. J., Svihra, P., Kelly, N. M., and Standiford, R. B. 2005. Sudden oak death in California: Disease progression in oaks and tanoaks. For. Ecol. Manage. 213:71-89.

33. McPherson, B. A., Wood, D. L., Storer, A. J., Svirha, P., Rizzo, D. M., Kelly, N. M., and Standiford, R. B. 2000. Oak mortality syndrome: sudden death of oaks and tanoaks. Calif. Dep. For. Tree Note No. 26.

34. Mikes, V., Milat, M.-L., Ponchet, M., Panabieres, F., Ricci, P., and Blein, J.-P. 1998. Elicitins, proteinaceous elicitors of plant defense, are a new class of sterol carrier proteins. Biochem. Biophys. Res. Commun. 245:133-139.

35. Pernollet, J.-C., Sallantin, M., Sallé-Tourne, M., and Huet, J.-C. 1993. Elicitin isoforms from seven Phytophthora species: comparison of their physico-chemical properties and toxicity to tobacco and other plant species. Physiol. Mol. Plant Pathol. 42:53-67.

36. Qutob, D., Huitema, E., Gijzen, M., and Kamoun, S. 2003. Variation in structure and activity among elicitins from Phytophthora sojae. Mol. Plant Pathol. 4:119-124.

37. Qutob, D., Kamoun, S., and Gijzen, M. 2002. Expression of a Phytophthora sojae necrosis-inducing protein occurs during transition from biotrophy to necrotrophy. Plant J. 32:361-373.

38. Ricci, P. 1997. Induction of the hypersensitive response and systemic acquired resistance by fungal proteins: The case of elicitins. Pages 53-75 in: Plant-Microbe Interactions. G. Stacey and N. T. Keen, eds. Chapman \& Hall, New York.

39. Rizzo, D. M., and Garbelotto, M. 2003. Sudden oak death: Endangering California and Oregon forest ecosystems. Front. Ecol. Environ. 1:197204.

40. Rizzo, D. M, Garbelotto, M., Davidson, J. M., Slaughter, G. W., and Koike, S. T. 2002. Phytophthora ramorum as the cause of extensive mortality of Quercus spp. and Lithocarpus densiflorus in California. Plant Dis. 86:205-214.

41. Robin, C., Capron, G., and Desprez-Loustau, M. L. 2001. Root infection by Phytophthora cinnamomi in seedlings of three oak species. Plant Pathol. 50:708-716.

42. Robin, C., and Desprez-Loustau, M. L. 1998. Testing variability in pathogenicity of Phytophthora cinnamomi. Eur. J. Plant Pathol. 104:465-475.

43. Scharte, J., Schön, H., and Weis, E. 2005. Photosynthesis and carbohydrate metabolism in tobacco leaves during an incompatible interaction with Phytophthora nicotianae. Plant Cell Environ. 28:14211435.

44. Schnabel, G., Strittmatter, G., and Noga, G. 1998. Changes in photosynthetic electron transport in potato cultivars with different field resistance after infection with Phytophthora infestans. J. Phytopathol. 146:205-210.

45. Tyler, B. M., Tripathy, S., Zhang, X., Dehal, P., Jiang, R. H. Y., Aerts, A., Arredondo, F. D., Baxter, L., Bensasson, D., Benynon, J. L., Chapman, J., Damasceno, C. M. B., Dorrance, A. E., Dou, D., Dickerman, A. W., Dubchak, I. L., Garbelotto, M., Gijzen, M., Gordon, S. G., Govers, F., Grunwald, N. J., Huang, W., Ivors, K. L., Jones, R. W., Kamoun, S., Krampis, K., Lamour, K. H., Lee, M.-K., McDonald, H., Medina, M., Meijer, H. J. G., Nordberg, E. K., Maclean, D. J., Ospina-Giraldo, M. D., Morris, P. F., Phuntumart, V., Putnam, N. H., Rash, S., Rose, J. K. C., Sakihama, Y., Salamov, A. A., Savidor, A., Scheuring, C. F., Smith, B. M., Sobral, B. W. S., Terry, A., Torto-Alalibo, T. A., Win, J., Xu, Z., Zhang, H., Grigoriev, I. V., Rokhsar, D. S., and Boore, J. L. 2006. Phytophthora genome sequences uncover evolutionary origins and mechanisms of pathogenesis. Science 313:1261-1266.

46. Vleeshouwers, V. G. A. A., van Dooijeweert, W., Govers, F., Kamoun, S., and Colon, L. 2000. The hypersensitive response is associated with host and nonhost resistance to Phytophthora infestans. Planta 210:853-864.

47. Wendehenne, D., Binet, M.-N., Blein, J.-P., Ricci, P., Pugin, A. 1995. Evidence for specific, high-affinity binding sites for a proteinaceous elicitor in tobacco plasma membrane. FEBS Lett. 374:203-207. 